TEME, г. XLIV, бр. 1, јануар - март 2020, стр. 97-119

\begin{tabular}{lr}
\hline \hline Оригинални научни рад & https://doi.org/10.22190/TEME171107011S \\
Примљено: 7. 11. 2017. & UDK 159.9.07 \\
Ревидирана верзија: 20. 12. 2019. & $613.89-057.875$
\end{tabular}

Одобрено за штампу: 20. 2. 2020.

\title{
COPING STRATEGIES AND THE DIMENSIONS OF ATTACHMENT IN STUDENTS
}

\author{
Tatjana Stefanović Stanojević ${ }^{1 *}$, Jasmina Nedeljković \\ ${ }^{1}$ University of Niš, Faculty of Philosophy, Niš, Serbia \\ ${ }^{2}$ Faculty of Legal Of Business Studies Dr Lazar Vrkatić, Novi Sad, Serbia \\ *stanja63@gmail.com
}

\begin{abstract}
The paper focuses on the relationship between the dimensions of affective attachment and a three-dimensional model of coping strategies (problem-focused coping, emotionfocused coping and avoidance: distraction and social diversion). To analyze this problem, the Coping in Stressful Situations questionnaire (CISS, Endler \& Parker, 1990) along with the Questionnaire for Attachment Assessment (UPIPAV -R, Hanak, 2004; Hanak 2011) was used on a sample of 152 students of the Faculty of Philosophy.

The results indicate the existence of significant correlations between coping strategies and the dimensions of attachment. Specifically, there is a negative correlation between problem-focused coping and unresolved family trauma, fear of using an outside secure base and a negative working model of self, while there is a positive correlation with the ability to mentalize. There is a positive correlation between emotion-focused coping and distraction strategies, and fear of using an outside secure base, a negative working model of self and negative working model of others, and poor anger management where there is a positive correlation between emotion-focused coping and unresolved family trauma. Finally, there is a negative correlation between social diversion and unresolved trauma, and a negative working model of self and a positive one between fear of using an outside secure base. The results of the regression analysis indicate that the aforementioned dimensions of affective attachment, as predictors explain $21,1 \%$ of the variance of problem-focused coping, $13,3 \%$ of the variance of the distraction strategy, $24,6 \%$ of the variance of the strategy of social diversion, and as much as $49,9 \%$ of the variance of emotion-focused coping.

Even though drawing any conclusions requires a greater sample, we could say that the participants are more prone to maladaptive coping if they display more pronounced dimensions of affective attachment typical of insecure patterns of attachment (a negative working model of self and a negative working model of others, unresolved family trauma, fear of using an outside secure base and poor anger management).
\end{abstract}

Key words: coping strategies, dimensions of attachment, students. 


\title{
СТРАТЕГИЈЕ ПРЕВЛАДАВАЫА СТРЕСА И ДИМЕНЗИЈЕ АФЕКТИВНЕ ВЕЗАНОСТИ КОД СТУДЕНАТА
}

\begin{abstract}
Апстракт
У овом раду нагласак је на односу димензија афективне везаности и тродимензионалног модела превладавања стреса (превладавање усмерено на проблем, превладавање усмерено на емоције и избегавање: дистракција и социјална диверзија). Са циљем испитивања наведеног проблема, на узорку од 152 студента Филозофског факултета, у раду су примењени Упитник суочавања са стресним ситуаиијама (ЦИСС, Ендлер и Паркер, 1990) и Упитник за процену димензија афективне везаности (УПИПАВ, Ханак, 2004). Резултати указују на постојање значајних корелација између начина суочавања са стресом и димензија афективне везаности. Конкретно, превладавање усмерено на проблем у негативној је корелацији са неразрешеном породичном трауматизацијом, страхом од коришћења спољашње базе сигурности и негативним моделом селфа, док је у позитивној корелацији са капацитетом за ментализацију. Превладавање усмерено на емоције и стратегија дистракције позитивно корелирају са страхом од коришћења спољашње базе сигурности, негативним моделом селфа и других, те слабом регулацијом беса, при чему је превладавање усмерено на емоције позитивно повезано и са неразрешеном породичном трауматизацијом. На крају, социјална диверзија значајно негативно корелира са неразрешеном траумом и негативним моделом селфа и позитивно са страхом и коришћењем спољашње базе сигурности. Резултати регресионе анализе показују да наведене димензије афективне везаности као предиктори објашњавају $21,1 \%$ варијансе стратегије суочавања усмерене на проблем, 13,3\% варијансе стратегије дистракције, 24,6\% варијансе стратегије социјалне диверзије и чак 49,9\% варијансе стратегије превладавања усмерене на емоције. Иако је за закључивање неопходан већи узорак, може се рећи да су субјекти истраживања утолико склонији неповољнијим стратегијама превладавања стреса уколико су код њих израженије димензије афективне везаности типичне за несигурне обрасце везаности (негативан модел селфа и других, неразрешена породична трауматизација, страх од коришћења спољашње базе сигурности и слаба регулација беса).
\end{abstract}

Кључне речи: стратегије превладавања стреса, димензије афективне везаности, студенти.

\section{THE INTRODUCTION OR WHY STUDIES CORRELATION PATTERNS OF ATTACHMENT AND COPING STRATEGIES ARE IMPORTANT}

First of all, in theory, and for decades now and in research as well, the quality of the affective attachment established in early childhood is connected with numerous and significant choices and events later on in life (Cassidy and Shaver, 2008). On the other hand, stress is a part of people's lives all over the world, and we dare say in Serbia even more so than in other environments. Considering that stress is an inevitability of human existence, the question of coping strategies seems especially important. Some means of coping with stress are significantly more effective than others (Cassidy, 1994). The question is, what do certain individuals base their choices on, that is, why does every individual not choose the most 
effective means of coping with stress. In this paper we attempted to determine whether the means of reacting to stress are connected to patterns of affective attachment. If they are, do the so-called insecure patterns more frequently lead to maladaptive reactions to stress? If this is correct, we are left with the option of educating mothers or guardians to, during early interaction, establish a pattern of attachment which optimizes the chance of the child's stress processing to be the most adequate possible.

\section{AFFECTIVE ATTACHMENT: INDIVIDUAL DIFFERENCES}

Affective attachment refers to the specific relationship which is formed between a mother and child in early childhood and lasts during one's entire life, as a permanent psychological connection established between two people (Bowlby, according to Holmes, 1993). After Bowlby determined the theoretical framework, the Canadian scientist Mary Ainsworth (19131999) operationalized the theory and enabled the evaluation of individual differences within attachment theory. Namely, Mary Ainsworth designed an experimental laboratory procedure (Ainsworth \& Witting, 1969) whose aim is to evaluate the relations between attachment and behavior under stress, that is, separation anxiety in the "strange situation" conditions. According to the theory of affective attachment, only one type of behavior in this situation is innate, and that is seeking out one's mother when she leaves and calming down when she returns (the primary strategy). Of course, children also react using the so-called secondary strategies, which refer to the adaptation to specific experiences acquired through daily contact with the mother. Individual differences are systematized in the following classification (Ainsworth, Blehar, Waters \& Wall, 1978):

Secure affective attachment - Children with this type of attachment will be upset by the mother's leaving in the experimental situation, which is why they will look for her, or cry and call for her, but once she has returned, they will immerse themselves into the safety of her embrace, calm down and continue playing (the primary strategy). In a word, these mothers are a secure base from which the child is to venture out and explore, as well as a source of comfort following separation. Adults with a secure affective attachment are characterized by trust of themselves and trust of others. What this means is that an individual with secure affective attachment possesses the capacities to cope with stress. According to Komorowska-Pudło (2016), an individual with secure affective attachment possesses: sense of security (Kuczyńska, 2001), and trust (Rostovski, 2003), ranging to emotional maturity (Belski, Cassidi, 1994), a sense of openness towards others and the belief that others can be relied on (Liberman, Doile, Markievicz, 1995), and self-respect (Bee, 2004; Bowlby, 1988), consistent structure (Mikulincer, 1995), competence, creativity (Plopa, 2008,) social skills (Liberman, Doile, Markievicz, 1995; Bee, 2004) and an adequate perception of stressors and selectivity in behavior in relation to stressors (Plopa, 2003). 
Insecure/ambivalent affective attachment - In the experimental situation, these babies cry when the mother leaves, but are not soothed by her return. They are ambivalent, seek contact, but when they achieve it, they cannot remain calm, cannot relax (the secondary strategy). Where does this strategy originate from? If we knew that the mothers from this category react selectively to the signals and needs of their children, it becomes clearer that there is uncertainty regarding the mother's presence which leads to the need of the children to control them and thus ensure their presence. Adults with these patterns of behavior are characterized by a negative working model of self and a positive working model of others (Stefanovic Stanojevic, 2010).

Also, according to Komorowska-Pudło (2016), these individuals are characterized by: a pronounced sense of insecurity, increased caution (Plopa, 2008), low self-esteem (Cassidi, 1988; Sroufe, 1985), anxiety (Marchvicki, 2012), a sense of inadequacy (Brennan, Morns, 1997; Plopa, 2008), helplessness (Czub, 2003), emotional immaturity (Greenberg, 1999), impulsivity (Bowlby, 1988; Czub, 2003) which results in an increase in sensitivity to stress (Plopa, 2008; Marchvicki, 2012). What is more, it has been determined that individuals who have formed preoccupied affective attachments are more often prone to depression and are more likely to resort to alcohol (Brennan, Shaver, Tobei, 1991).

Insecure/avoidant affective attachment - In the "strange situation" these children, once their mother leaves, do not cry, do not look for their mother, do not display any open signs of distress. They react neither to her departure nor to her return, accustomed to their expectations not being satisfied, and meeting their mother's expectations by not reacting (the secondary strategy). Where does this type of behavior originate from? In the category of insecure/avoidant children, the mothers are rather consistent in not reacting to signals and needs, which does not mean that they are not involved in their children's lives, but that they do so as part of a regimen which they consider to be more appropriate. Which is why the children are forced to endure the so-called PDD: Protest, Desperation and finally Detachment, thinking that they do not need anyone (Bowlby, Robertson, 1952). Adults with this pattern of attachment are characterized by a negative working model of others and a defensive positive working model of self. When faced with stress, these individuals exhibit signs of unease and tension (Troi, Sroufe, 1987), withdrawal from contact with others (Cassidi, 1988; Plopa, 2008), a low level of emotional maturity, impulsivity and agitation (Bartholomev, Horovitz, 1991; Brennan, Bosson, 1998; Rostovski, 2003), aggression (Stavicka, 2001), hostility (Stavicka, 2001; Clarke-Stevart et al., 1988, according to Rostovski, 2003), vengefulness (Erickson, Sroufe, Egeland, 1985, according to Stavicka, 2008). Individuals with avoidance affective attachment risk more than people with other styles of attachment (Sroufe et al., 2000, following Czub, 2003; Gentzler, Kerns, 2004), and 
resort to alcohol, drugs and other stimulants (Bartholomev, Horovitz, 1991; Brennan, Bosson, 1998, according to Rostovski, 2003).

Insecure/disorganized affective attachment - Main \& Solomon (1986) defined the fourth category of affective attachment by naming it disorganized or disoriented attachment. Namely, after years of observing children in the "strange situation", it became obvious that in addition to the described coping strategies, there are forms of behavior which are difficult to classify as belonging to any of the known strategies. It turned out that there are children who do not have an organized strategy to prevent their parents from leaving the room, and even fewer strategies with which to greet them. In short, these children do not exhibit a coherent manner of coping with stress caused by separation (Stefanovic Stanojevic, Tosic Radev, Stojilkovic, 2017). Adults with these patterns of attachment are characterized by a negative working model of self and a negative working model of others when faced with stress. Disorganized-disoriented insecure attachment, a pattern common in infants abused during the first 2 years of their life, is psychologically manifest as an inability to generate a coherent strategy for coping with relational stress.

In an attempt to integrate the socially personal and clinical approach to the phenomenon of attachment, the concept of understanding the quality of attachment through the dimensions of affective attachment was defined. The concept was operationalized using the UPIPAV instrument (Hanak, 2004), and later in a revised version UPIPAV-R (Hanak, 2011). The dimensions of the revised instrument include: Unresolved trauma, Poor anger management, the Ability to mentalize, the Ability to use an outside secure base, Fear of losing the outside secure base, a Negative working model of self, and a Negative working model of others. A greater number of dimensions enable a more precise understanding of the functioning and psychological structure of an individual's personality. This is why we opted for the dimensional approach in this study.

\section{STRESS AND COPING STRATEGIES}

When outlining the phenomenon of stress, we must mention Hans Selye (1907-1982). Selye was the first to use the concept of stress with the purpose of understanding the physiological responses to threats to the human body. The term stress itself was explained by bodily reactions which significantly threaten the balance in the human body. Reactions with the aim of adapting, that is, maintaining internal balance, he referred to as the general adaptation syndrome. This syndrome has three successive stages (Selye, 1956): the alarm stage (it begins with the appearance of the stressor which threatens to disrupt the homeostasis); the resistance stage (during this stage the body tries to adapt to the new conditions using defense mechanisms); and the exhaustion stage (this is the breaking point of the defenses which might lead to illness). 
And while stress is a relatively old and frequent topic of study, only three decades later, in the period between 1956-1984, did researchers begin to study the individual differences in coping with stress. Lazarus \& Folkman (1984) were one of the first to elaborate, in detail, on these coping strategies. They believed that when we find ourselves in a stressful situation, the way in which we observe and interpret the threatening content determines our response to stress. In order to understand the nature of psychological stress, it is also important to understand the cognitive processes which determine the type and intensity of a stressful reaction. The first variable to determine is that of a threat - the experience of a stimulus from our surroundings that we perceive as potentially dangerous. That is followed by the primary appraisal of the threat which is influenced by one's self-confidence and their level of anxiety. During the second process, or the secondary appraisal of the stressor, the person assesses the various options of behavioral responses to the stressor. That is referred to as coping. The basic functions of the secondary appraisal can move in a twofold direction - towards an active or passive response, that is, towards using problem-focused coping or emotion-focused coping (Lazarus \& Folkman, 1984; Folkman \& Moskowitz, 2004). Relying on Lazarus' model, Endler and Parker (1990) developed a model based on which the individual possesses an inventory of various coping styles, which they use in various situations:

1. Task-oriented coping refers to either solving the problem or taking action. Orientation on the task itself and solving the problem changes the individual-environment relationship, either through direct action or a cognitive reconstruction. Individuals who are oriented towards the future plan, consider the best means of overcoming the problem and coping with stress. This is fully compatible with their efforts to find moral support, empathy, sympathy and understanding for the situation they find themselves in from their social environment (Kostić \& Nedeljković, 2013).

2. Emotion-oriented coping is a style of coping where stress functions as a means of reducing or coping more easily with the emotional tension caused by the stressor. In addition, it includes various strategies which refer to openly expressing emotions, and looking for social support as a result of emotional and instrumental reasons. These strategies do not directly alter the stressful situation.

3. Avoidance-oriented coping refers to the cognitive, emotional or behavioral attempts to distance oneself from any kind of stress caused either by psychological or physical reactions to the stressor. Not taking or avoiding action that is oriented towards the problem, negation of the fact that the event happened, isolation, repression of emotion, consumption of alcohol and drugs, fantasizing, daydreaming, going out at night and self-destructive behavior are just a few of the avoidance strategies. This coping strategy includes distraction and social diversion. Distraction refers to focusing on a task which is not associated with the stressful situation. This style is 
maladaptive. Social diversion is reflected in increased socialization with people. When faced with a threat, the person turns to others in order to avoid dealing with the problem.

What does our choice depend on? Does the quality of our early interaction with our mother, or guardian, determine the way we cope with stress?

It happens that children experience numerous and different kinds of stress. What could they do about it? In situations when exposed to a stressor they will rely on their evaluation of the signals they read from the faces of their guardians. For the human infant, his mother is the world, from her face the infant perceives the world as being either dangerous and fearful or friendly and supportive. In addition, the baby sees a reflection of itself in the mother and slowly compiles an image of itself, as a beloved and precious being or a being which is neither loved nor precious. Thus, the baby's reaction will be a consequence of the signals sent by the figure with which it has developed an affective attachment. The evaluation of the danger will depend on the mother's facial expression. A supportive and adequate mother has the ability to make the world a comfortable place for her baby even when the circumstances are not ideal, just like a mother overwhelmed by her own fears can even in relatively decent living conditions send its child an image of the world as an uncertain, unfriendly, and even frightening place. Individual differences in the way people cope with stress could be tied to these early images of oneself and the world at large. Children who believe in themselves and others will learn that stress can be coped with. Children trapped in their negative experiences of themselves and/or the world at large will be more prone to less adaptive strategies of coping.

What do the research results indicate? These assumptions about the relationship between personality characteristics defining each of the four attachment styles with preference for specific strategies for coping with stress have been confirmed in many studies. We will include only some of the existing studies: Turkish students with a secure attachment style, more often than students with an insecure style, undertook active planning of problems solving and sought external support in difficult situations. However, they would rarely undertake avoidant behavior both in the behavioral and mental area (Terzi, 2013). In other studies involving students, it was found that people with an anxious-ambivalent attachment style strongly reacted to difficult situations - they were more vulnerable to the perception and interpretation of events as stressful (Pielage, Gerlsma, Schaap, 2000). In adult respondents from New Zealand, avoidant attachment style in stressful situations correlated positively with denial and mental withdrawal, and negatively with the search for emotional and instrumental support. An anxious-ambivalent attachment style was positively correlated with denial and both behavioral and mental withdrawal shown in stress response, and with resorting to alcohol and drugs in those situations, and negatively 
correlated with an active and planned attitude to problem solving, and choosing such a coping strategy in the search for instrumental support (Baker, 2006). Another research conducted on a group of Polish nurses showed that secure attachment styles are an important predictor of dealing with difficult circumstances. In this study insecure attachment styles were associated with undertaking destructive or ineffective behaviors in difficult situations. The avoidant attachment style correlated negatively with the search for social support, with planning to solve the problem, with a positive estimation of the problem, as well as with avoidance of difficult situations. However, the anxious-ambivalent attachment style correlated positively with taking on responsibility for solving a problem themselves on the part of the nurses (Franczak, 2012).

In another study conducted among security guards working in the Belgian Red Cross, a negative relation between post-traumatic stress and the secure attachment style of the respondents, and a positive relation with both the avoidant and anxiety-ambivalent style were determined (Declercq, Willemsen, 2006). The research on the war experiences of respondents and the risk of disorders known as post-traumatic stress disorder (PTSD) shows that people with a secure attachment style work constructively in difficult situations and turn to others for emotional and instrumental support (Mikulincer, Florian, Weller, 1993; Mikulincer, Florian, 1995; Mikulincer, Shaver, 2003). People with insecure attachment styles often have negative thoughts and memories of stressful situations, and studies have revealed a positive correlation between these two styles and PTSD (Mikulincer, Florian, Weller, 1993; Mikulincer, Florian, 1995). Other studies show that anxiety-ambivalent people are also hypersensitive towards the problems encountered (Bartholomew, Horowitz, 1991), that they have trouble opening up to look for support from others, and that their ways of coping with stress are based on emotions and distancing themselves from others (Mikulincer, Florian, Weller, 1993; Mikulincer, Florian, 1995). People with avoidant attachment style manifest higher levels of somatization in difficult situations, hostility and avoidance. They distance themselves from others and are less likely to seek support (Mikulincer, Florian, 1995).

\section{THE RESEARCH PROBLEM}

The subject of the research was the issue of the possible correlations between various responses to stress (problem-focused coping, emotionfocused coping, avoidance-focused coping, distraction or social diversion) and the dimensions of affective attachment.

The research hypotheses are:

(H0) A correlation is expected between coping strategies and the dimensions of affective attachment. 
(H1) It is expected that there will be a positive correlation between Problem-focused coping and the ability to mentalize and the ability to use an outside secure base, and a negative correlation with the dimensions which refer to the negative aspects of attachment (fear of using an outside secure base, poor anger management, unresolved trauma and a negative working model of and negative working model of others).

An explanation of the hypothesis: It is assumed that individuals capable of coping with stress by solving problems have a positive working model of self (Holmberg, et al, 2011). Thus, they are self-confident and ready to rely on themselves when solving problems. A positive working model of self means that these individuals have learned to use their ability to mentalize (the understanding of their own and other people's emotions). In addition, it might be assumed that those solving the problems can also rely on others when they deem it necessary to do so, which means they also have a positive working model of others. Thus, they are also ready to rely on their outside secure base. All the other dimensions of $\mathrm{AA}^{1}$ indicate an insecure affective attachment, so a negative correlation is expected between those who are able to focus on the problem and these dimensions.

(H2) A positive correlation is expected between Emotion-focused coping and the dimensions which indicate the negative aspects of attachment, and a negative correlation with mentalization.

An explanation of the hypothesis: Emotion-focused coping belongs to the group of ineffective coping strategies (Alexander et al., 2001). Instead of solving the problem, that person remains stuck in a flood of their own emotions. Therein lies the expectation that there will be a positive correlation between individuals of this type and the so-called negative dimensions of $\mathrm{AA}$, and a primarily negative one with the Ability to mentalize, that is, the ability to think about and understand the situation. No negative correlation is expected with the Ability to use an outside secure base, since individuals of this type mostly have a negative working model of self but a positive working model of others, and so will be prone to sharing the emotions which overwhelm them with others.

(H3) It is expected that there will be a positive correlation between Avoidance-focused coping and the dimensions which refer to the negative aspects of attachment, and a negative correlation with Mentalization and the Ability to use an outside secure base.

Explanation of the hypothesis: Avoidance-focused coping has two aspects. Distraction and social diversion. Individuals prone to distraction will run from the problem by focusing on another task, while individuals prone to diversion will escape into socializing, enjoyment, etc. None of the

\footnotetext{
${ }^{1}$ AA- Affective Attachment
} 
described strategies solves the problem, that is, the aforementioned strategies belong to non-adaptive coping strategies.

(H4) It is expected that we can predict coping strategies based on the dimensions of affective attachment, in accordance with the previously established expectations of correlations.

\section{RESEARCH VARIABLES AND MEASURING INSTRUMENTS}

The dimensions of affective attachment are: Fear of losing an outside secure base, the Ability to mentalize, Unresolved family trauma, a Negative working model of self, a Negative working model of others, Using an outside secure base and Anger management. These variables are operationalized by the scores achieved on the sub-scales of the Questionnaire for Attachment Assessment (UPIPAV-R, Hanak, 2011). The Questionnaire for Attachment Assessment (UPIPAV-R) evaluates the basic aspects of attachment, conditioned by the analysis of the theory and existing instruments for the evaluation of attachment at the level of mental representations. This is a revised version of the Questionnaire for Attachment Assessment (UPIPAV $R$, Hanak, 2011). It consists of a total of 77 items which measure affective attachment by means of seven dimensions (11 items each): fear of losing an outside secure base, the ability to mentalize, unresolved family trauma, a negative working model of self, a negative working model of others, using on an outside secure base and anger management. A number of studies have shown that the dimensional approach is more adequate, so we decided for the Serbian instrument for measuring these dimensions.

The participants evaluated the extent of their agreement with the provided claims on a seven-point Likert scale, where 1 corresponded to - I do not use it at all, and 7 to - I use them completely. The questionnaire consisted of claims which describe various feelings and attitudes towards oneself and others.

Coping strategies are general dispositions for a certain type of behavior under stressful circumstances (Zotović, 2004). In this paper, they are viewed through the following: problem-focused coping strategies, emotion-focused coping strategies, and avoidance strategies (Endler \& Parker, 1990). The coping strategies are measured using the following measuring instrument: the CISS - Coping Inventory for Stressful Situations (Endler \& Parker, 1990). The authors attempt to develop a way of measuring coping styles as stable personality traits. The questionnaire has 48 items divided into three sub-scales (16 items each): problem-focused strategies, emotion-focused strategies and avoidance-focused strategies (there are also two subscales for the Avoidance-Oriented scale: Distraction, and Social Diversion). The participants evaluated the extent to which they used certain types of activities in coping with stressful situations on a fivepoint Likert scale, where 1 corresponded to - I do not use it at all, and 5 - I use them completely (Endler \& Parker, 1990). 


\section{SAMPLE}

We used a non-probability sampling procedure, i.e. voluntary response sampling on a population of students. The sample consisted of 152 students, but the male and female sub-samples were not of equal size (18 males and 134 females). They are all students at the Faculty of Philosophy in Niš, Psychology Department (118) and the Pedagogy Department (34). The average age of the participants was 20.6.

\section{RESEARCH RESULTS}

Descriptive statistics

Table 1. The average values deviations and $\alpha$-Cronbach of coping strategies

\begin{tabular}{lrrrrrc}
\hline & N & Min & Max & M & \multicolumn{1}{c}{ SD } & $\alpha$ \\
\hline Problem-focused coping & 152 & 44 & 79 & 63.26 & 7.592 & 0.80 \\
Emotion-focused coping & 152 & 30 & 77 & 51.43 & 9.461 & 0.83 \\
Distraction & 152 & 10 & 46 & 26.36 & 7.974 & 0.79 \\
Social diversion & 152 & 6 & 30 & 22.12 & 4.834 & 0.75 \\
Avoidance-focused coping & 152 & 20 & 73 & 48.47 & 11.257 & 0.77 \\
\hline
\end{tabular}

The theoretical range of the scores on the Coping Inventory for Stressful Situations is from 16 to 80. On the questionnaire focusing on coping strategies, the participants achieved the highest scores on the Problemfocused coping sub-scale $(M=63.26)$. On this questionnaire, the participants achieved the lowest average values for the Avoidance-focused coping subscale $(M=48.47)$. The greatest deviations from the average values was recorded for the Avoidance-focused coping sub-scale $(\mathrm{SD}=11.257)$.

Table 2. Average values, standard deviations and $\alpha-C r o n b a c h$ for the dimensions of affective attachment

\begin{tabular}{lcccccc}
\hline & $\mathrm{N}$ & Min & Max & M & \multicolumn{1}{c}{ SD } & $\alpha$ \\
\hline Unresolved trauma & 152 & 11 & 74 & 29.75 & 14.783 & 0.89 \\
Fear of losing an outside secure base & 152 & 13 & 74 & 45.78 & 12.160 & 0.85 \\
Negative model of others & 152 & 14 & 75 & 43.65 & 12.060 & 0.84 \\
Mentalization & 152 & 32 & 77 & 57.76 & 9.320 & 0.72 \\
Negative model of self & 152 & 11 & 74 & 29.59 & 13.302 & 0.83 \\
Using an outside secure base & 152 & 23 & 77 & 61.82 & 10.945 & 0.86 \\
Poor anger management & 152 & 12 & 63 & 31.72 & 11.123 & 0.78 \\
\hline
\end{tabular}

The theoretical range of the scores on the subscales of the Questionnaire for Attachment Assessment is from 11 to 77. On the Questionnaire for Attachment Assessment, the greatest average values were obtained for the sub-scales of Using an outside secure base $(\mathrm{M}=61.98)$ and 
Mentalization ( $M=57.76)$. The lowest average values on this questionnaire were achieved for the sub-scales of the Negative working model of self $(\mathrm{M}=$ 29.59) and Unresolved trauma $(M=29.75)$. The greatest deviation from the average values was determined for the Unresolved trauma sub-scale (SD = 14.783).

Thus, on the studied sample, the most prominent type of coping is problem-focused, while the dominant dimensions of affective attachment are Using an outside secure base and the Ability to mentalize.

\section{THE CORRELATION BETWEEN THE RESEARCH VARIABLES}

Table 3. The correlations between the dimensions of $A A$ and the coping strategies

\begin{tabular}{|c|c|c|c|c|c|c|}
\hline & & $\begin{array}{l}\text { Problem- } \\
\text { focused }\end{array}$ & $\begin{array}{l}\text { Emotion- } \\
\text { focused }\end{array}$ & $\begin{array}{l}\text { Avoidance- } \\
\text { focused }\end{array}$ & Distraction & Diversion \\
\hline Unresolved trauma & $\mathrm{r}$ & $-0.16^{*}$ & $0.316^{* *}$ & -0.047 & 0.078 & $-0.237^{*}$ \\
\hline Fear of losing OSB & $\mathrm{r}$ & $-0.259^{* *}$ & $0.523^{* *}$ & $0.298^{* *}$ & $0.26^{* *}$ & $0.266^{* *}$ \\
\hline Negative model of others & $\mathrm{r}$ & -0.11 & $0.353^{* *}$ & 0.072 & $0.161^{*}$ & -0.099 \\
\hline Mentalization & $\mathrm{r}$ & $0.195^{*}$ & 0.133 & -0.109 & -0.134 & -0.033 \\
\hline Negative model of self & $\mathrm{r}$ & $-0.345^{* *}$ & $0.552^{* *}$ & 0.034 & $0.189^{*}$ & $-0.233^{* *}$ \\
\hline Using OSB & $\mathrm{r}$ & 0.067 & 0.098 & $0.209^{*}$ & 0.036 & $0.427^{* *}$ \\
\hline Poor anger management & $\mathrm{r}$ & -0.059 & $0.353^{* *}$ & 0.125 & $0.242^{* *}$ & -0.109 \\
\hline
\end{tabular}

The correlations indicated in Table 3 point to a statistically significant correlation between the dimensions of affective attachment and the coping strategies for the entire sample. There is a statistically significant negative correlation between problem-focused coping and three of the so-called negative dimensions of AA (Unresolved trauma, Fear of losing OSB, Negative working model of self), and a positive one with Mentalization. There is a statistically significant positive correlation between emotion-focused coping and the so-called negative dimensions of AA (Unresolved trauma, Fear of losing OSB, Negative working model of others, Negative working model of self and Poor anger management). There is a statistically significant positive correlation between distraction and four negative dimensions of AA (Fear of losing OSB, Negative working model of others, Negative working model of self and Poor anger management), while there is a positive correlation between Social diversion and two negative dimensions (Unresolved trauma, and Negative working model of self), but also a positive correlation with the Ability to use an outside secure base. There is a statistically significant positive correlation between Social diversion, on the one hand, and Fear of losing OSB an outside secure base and the Ability to use an outside secure base, on the other. 


\section{THE PROGNOSTIC ROLE OF AFFECTIVE ATTACHMENT TO COPING MECHANISMS}

Table 4. The parameters for the evaluation of a regression analysis model with predictors of the UPIPAV-R dimensions for the criterion variable of problem-focused coping

\begin{tabular}{cccc}
\hline $\mathrm{R}$ & $\mathrm{R}^{2}$ & $\mathrm{~F}$ & $\mathrm{p}$ \\
\hline 0.459 & 0.221 & 5.498 & $<0.05$ \\
\hline
\end{tabular}

The predictive model of the dimensions of affective attachment for problem-focused coping is statistically significant. The predictor variables explain $22.1 \%$ of the variance in this coping strategy.

Table 5. The individual predictive power of the dimensions of $A A$ for problem-focused coping

\begin{tabular}{lcrc}
\hline UPIPAV-R Dimensions & \multicolumn{1}{c}{$\mathrm{t}$} & $\mathrm{p}$ \\
\hline Unresolved trauma & -.005 & -.050 & $>0.05$ \\
Fear of losing an outside secure base & -.229 & -2.318 & $<0.05$ \\
Negative model of others & .073 & .798 & $>0.05$ \\
Mentalization & .233 & 2.785 & $<0.01$ \\
Negative model of self & -.346 & -3.323 & $<0.01$ \\
Using an outside secure base & .007 & .064 & $>0.05$ \\
Poor anger management & .111 & 1.303 & $>0.05$ \\
\hline
\end{tabular}

The following dimensions have emerged as individually significant predictors of the problem-focused coping strategy: fear of losing an outside secure base, mentalization and negative working model of self. Focus on solving problems is found among students with low values for fear of losing their OSB and a negative working model of self, and high values for mentalization.

Table 6. The parameters for the evaluation of the regression analysis model with predictors of the UPIPAV-R dimensions for emotion-focused coping

\begin{tabular}{cccc}
\hline $\mathrm{R}$ & $\mathrm{R}^{2}$ & $\mathrm{~F}$ & $\mathrm{p}$ \\
\hline 0.706 & 0.499 & 20.499 & $<0.01$ \\
\hline
\end{tabular}

The dimensions of affective attachment explain almost $50 \%$ of the variance in individual differences for emotion-focused coping. The obtained prediction model is statistically significant. 
Table 7. The individual predictive power of the dimensions of $A A$ for emotion-focused coping

\begin{tabular}{lcrc}
\hline UPIPAV-R Dimensions & $\beta$ & $\mathrm{t}$ & $\mathrm{p}$ \\
\hline Unresolved trauma & -.013 & -.165 & $>0.05$ \\
Fear of losing an outside secure base & .322 & 4.091 & $<0.01$ \\
Negative model of others & .037 & .504 & $>0.05$ \\
Mentalization & .106 & 1.590 & $>0.01$ \\
Negative model of self & .427 & 4.990 & $<0.01$ \\
Using an outside secure base & .100 & 1.118 & $>0.05$ \\
Poor anger management & .177 & 2.595 & $<0.05$ \\
\hline
\end{tabular}

The following dimensions emerged as independently significant predictors of emotion-focused coping strategies: fear of losing an outside secure base, negative working model of self and poor anger management. Focus on emotions is greater among students for whom the values for these three dimensions of affective attachment are high.

Table 8. The parameters for the evaluation of the regression analysis model with the predictors of the UPIPAV-R dimensions for the criterion variable avoidance-focused coping

\begin{tabular}{cccc}
\hline $\mathrm{R}$ & $\mathrm{R}^{2}$ & $\mathrm{~F}$ & $\mathrm{p}$ \\
\hline 0.373 & 0.139 & 3.328 & $<0.05$ \\
\hline
\end{tabular}

The regression model for coping based on avoidance is statistically significant and it can explain $13.9 \%$ of the variance in the criterion variable.

Table 9. The individual predictive power of the dimensions of $A A$ for avoidance-focused coping

\begin{tabular}{lcrc}
\hline UPIPAV-R Dimensions & $\beta$ & $\mathrm{t}$ & $\mathrm{p}$ \\
\hline Unresolved trauma & -.007 & -.088 & $>0.05$ \\
Fear of losing an outside secure base & .213 & 2.233 & $<0.05$ \\
Negative model of others & .038 & .429 & $>0.05$ \\
Mentalization & -.219 & -2.079 & $<0.05$ \\
Negative model of self & -.017 & -.178 & $>0.05$ \\
Using an outside secure base & .184 & 1.534 & $>0.05$ \\
Poor anger management & .087 & .965 & $>0.05$ \\
\hline
\end{tabular}

This stress coping strategy will be more developed among students who have higher scores for the dimension fear of losing an outside secure base and lower scores for mentalization. 
Table 10. The parameters for the evaluation of the regression analysis model with the predictors of the UPIPAV-R dimensions for the criterion variable of social diversion-focused coping

\begin{tabular}{cccc}
\hline $\mathrm{R}$ & $\mathrm{R}^{2}$ & $\mathrm{~F}$ & $\mathrm{p}$ \\
\hline 0.496 & 0.246 & 6.726 & $<0.05$ \\
\hline
\end{tabular}

The variance in social diversion (24.6\%) could be explained in a statistically significant manner based on the interaction between the dimensions of affective attachment.

Table 11. The individual predictive power of the dimensions of $A A$ for social diversion-focused coping

\begin{tabular}{lcrc}
\hline UPIPAV-R Dimensions & $\beta$ & $\mathrm{t}$ & $\mathrm{p}$ \\
\hline Unresolved trauma & .008 & .082 & $>0.05$ \\
Fear of losing an outside secure base & .169 & 1.752 & $>0.05$ \\
Negative model of others & .063 & .708 & $>0.05$ \\
Mentalization & -.193 & -2.356 & $<0.05$ \\
Negative model of self & -.169 & -1.607 & $>0.05$ \\
Using an outside secure base & .365 & 3.345 & $<0.01$ \\
Poor anger management & -.072 & -.861 & $>0.05$ \\
\hline
\end{tabular}

Two components of affective attachment have proved themselves to be independently significant predictors in explaining the variability in social diversion - mentalization and using an outside secure base. Coping strategies focused on social diversion will be more prevalent among participants with low mentalization and a high dimension of using an outside secure base.

Table 12. The parameters for the evaluation of the regression analysis model with the predictors of the UPIPAV-R dimensions for the criterion variable of distraction-focused coping

\begin{tabular}{cccc}
\hline $\mathrm{R}$ & $\mathrm{R}^{2}$ & $\mathrm{~F}$ & $\mathrm{p}$ \\
\hline 0.365 & 0.133 & 3.164 & $<0.05$ \\
\hline
\end{tabular}

A statistically significant regression model with the components of affective attachment as predictors was obtained. The model can explain $13.3 \%$ of the variance in the distraction-focused coping strategy. 
Table 13. The individual predictive power of the dimensions of AA for distraction-focused coping

\begin{tabular}{lrrc}
\hline UPIPAV-R Dimensions & $\beta$ & $\mathrm{t}$ & $\mathrm{p}$ \\
\hline Unresolved trauma & -.018 & -.171 & $>0.05$ \\
Fear of losing an outside secure base & .222 & 2.152 & $<0.05$ \\
Negative model of others & .020 & .204 & $>0.05$ \\
Mentalization & -.140 & -1.594 & $>0.01$ \\
Negative model of self & .074 & .658 & $>0.01$ \\
Using an outside secure base & .031 & .268 & $>0.05$ \\
Poor anger management & .165 & 1.845 & $>0.05$ \\
\hline
\end{tabular}

The distraction-focused strategy is more pronounced among the participants with higher values of fear of losing an outside secure base. The remaining predictors of affective attachment are not independently significant predictors of this coping strategy.

\section{DISCUSSION AND CONCLUSION}

(H0) The basic research hypothesis was partly confirmed. Most of the experienced correlations are statistically significant. The discussion will be organized around specific hypotheses, and in the conclusion we will refer to the general hypothesis.

(H1) A positive correlation was expected between problem-focused coping and the Ability to mentalize and the Ability to use an outside secure base, and a negative correlation with the dimensions which indicate the negative aspects of attachment (Fear of using an outside secure base, Poor anger management, Unresolved trauma and a Negative working model of self and Negative working model of others).

The research results have only partly confirmed the proposed hypotheses. There is a significant positive correlation between problemfocused coping and the Ability to mentalize, and a statistically significant negative correlation between it and three so-called negative dimensions of AA (Unresolved trauma, Fear of losing an outside secure base, Negative working model of self). No confirmation has been obtained on the existence of a statistically significant negative correlation with the dimensions of Negative working model of others and Poor anger management, but the direction of the obtained results indicates the possibility that on a larger sample we would have confirmed these hypotheses as well. Furthermore, this is the angle from which we can claim that individuals with a secure affective attachment will be most prone to the problem-focused coping strategy (a positive working model of self and model of others). Despite the noted significant negative correlation between it and the dimension of Negative working model of self, the dimension of Negative working model of others indicates the possibility that individuals with so-called avoidance-focused 
coping strategies are also prone to problem-focused strategies (a negative working model of others and a positive working model of oneself). Naturally, prior to the research on a bigger sample, this hypothesis only has the strength of a speculation. In addition, no statistically significant positive correlation between it and the dimension the Ability to use an outside secure base was obtained, but the positive direction of the correlation indicates the possibility of statistical significance on a larger sample. Thus, the results of the research have confirmed the expectation that individuals with a positive working model of self, that is, secure and avoidant affectively attached individuals will be more prone to coping strategies that are the most effective. The obtained results support the results of existing research (Terzi, 2013; Franczak, 2012).

(H2) A positive correlation was expected between emotion-focused coping and the dimensions which refer to the negative aspects of attachment, but also the Ability to use an outside secure base and a negative correlation with the Ability to mentalize. The research results confirm the existence of a statistically significant positive correlation between all the negative dimensions of AA, which leads us to the conclusion that individuals with a negative working model of self and a negative working model of others are more prone to this type of coping strategy (the disorganized pattern). However, no statistically significant correlation with the Ability to mentalize has been obtained. The correlation is positive, but it is not statistically significant. In addition, a positive (but not statistically significant) correlation was determined to exist with the Ability to use an outside secure base. The direction of the obtained findings opens up the possibility that this strategy is one that individuals with a preoccupied pattern might be prone to, which supports previous research results (Pielage, Gerlsma, Schaap, 2000; Baker, 2006; Bartholomew, Horowitz, 1991). The analysis of these final results will only be possible after a repeat study on a larger sample.

(H3) A positive correlation was expected between avoidancefocused coping and the dimensions which indicate the negative aspects of attachment, and a negative correlation with the Ability to mentalize and the Ability to use an outside secure base. The results only partially confirm this hypothesis. Namely, there is a positive correlation between the Avoidance strategy and the dimensions of Fear of losing an outside secure base and the Ability to use an outside secure base, while all the other correlations are not statistically significant. The picture becomes much clearer if we look at the results obtained for specific avoidance strategies: Distraction and Social diversion. There is a statistically significant correlation between Distraction and the Negative working model of self and Negative working model of others, and thus Poor anger management and the Fear of using an outside secure base (a disorganized pattern of attachment), and between Social diversion and Using an outside secure base, Fear of losing an outside secure base and a Negative working model of self (the preoccupied pattern of 
attachment). In addition, a statistically significant correlation was noted with Unresolved trauma. The obtained results partially support the results obtained in previous studies (Baker, 2006; Franczak, 2012). These findings require evaluation on a larger sample, but could currently be viewed in the light of predilections of individuals focused on social diversion for avoiding serious issues.

(H4) It is expected that it is possible to predict coping strategies based on the dimensions of affective attachment.

The research results only partly confirm these expectations. Primarily, based on the dimensions of affective attachment we could predict emotionfocused coping strategies (49.9\% of the variance). This finding is proof enough that individuals who develop a disorganized or preoccupied form of attachment in early interaction significantly struggle to deal with stress, or to cope with it effectively. Additional confirmation can also be found in the fact that the dimensions of affective attachment explain as much as $24.6 \%$ of the variance of the strategy of social diversion which is also typical of the preoccupied pattern. Over $20 \%$ of the variance $(21.1 \%)$ of problem-focused strategies can be explained by the dimensions of AA, which is also not negligible and confirms the importance of nurturing high quality early interaction.

As a conclusion to the discussion of the obtained results, we will single out the most important points:

- Coping strategies are connected to patterns of affective attachment formed early on in life.

- Individuals with disorganized and preoccupied patterns of affective attachment are more prone to maladaptive strategies of coping with stress.

- Individuals with secure and avoidance patterns of affective attachment are more prone to adaptive strategies of coping with stress.

\section{THE IMPLICATIONS AND DRAWBACKS OF THE RESEARCH}

The implications of the research primarily refer to the possible education of guardians on the importance of early interaction. A positive working model of self as the common denominator of individuals with secure and avoidant affective attachment patterns represents the first and basic precondition of the effective strategies of coping with life or stress. The conclusion is logical from a common-sense point of view, but it is also confirmed by the findings, which certainly makes it more convincing.

The drawbacks are numerous. Primarily they refer to the size and structure of the sample. Except for the age and status of the participants, other significant socio-demographic variables were not controlled. In the upcoming research, the sample might be more homogenous in terms of gender and certainly significantly greater in number. 


\section{REFERENCES}

Alexander, P.R., Feeney, J.A., Hohaus, L., Noller, P. (2001). Attachment style and coping resources as predictors of coping strategies in the transition to parenthood. Personal Relationships, Vol. 8 (2), 137-152

Ainsworth, M. D. S., \& Wittig, B. A. (1969). Attachment and exploratory behavior of one-year-olds in a strange situation. In B. M. Foss (Ed.), Determinants of infant behavior (Vol. 4, pp. 111-136). London: Methuen.

Ainsworth, M.D., Blehar, M, Waters, E, \& Wall, S. (1978) Patterns of Attachment: A Psychological Study of the Strange Situation, Hillsdale, NJ: Lawrence Erlbaum

Baker, J.K. (2006). The impact of attachment style on coping strategies, identity development and the perception of social support (s. 43-45), Canterbury: University of Canterbury.

Bartholomew, K., Horowitz, L.M. (1991). Attachment styles among young adults: a test of a four-category model. Journal of Personality and Social Psychology, 61, 226-244.

Bowlby, J., and Robertson, J. (1952). A two-year-old goes to hospital. Proceedings of the Royal Society of Medicine, 46, 425-427.

Bowlby, J. (1988). A secure base: Parent-child attachment and healthy human development. New York, NY, US: Basic Books.

Bee, H. (2004). Lifespam development, New York: Harper Collins.

Belsky, J., \& Cassidy, J. (1994). Attachment: Theory and evidence. In M. Rutte, \& D. Hay (Eds.), Development through life: A Handbook for Clinicians (pp. 373402). Oxford: Blackwell.

Brennan, K.A., Bosson, J.K. (1998), Attachment-Style Differences in Attitudes toward and Reactions to Feedback from Romantic Partners: An Exploration of the Relational Bases of Self-Esteem, 24, 699-714, Personality and Social Psychology Bulletin, , SAGE Journals.

Brennan, K.A., Morns, K.A. (1997). Attachment styles, self-esteem, and patterns of seeking feedback from romantic partners. 23, 23-31. Personality and Social Psychology Bulletin, SAGE Journals.

Brennan, K.A., Shaver, P.R., Tobey, AE. (1991). Attachment styles, gender, and parental problem drinking. Journal of Social and Personal Relationships, 8, 451-466. SAGE Journals.

Cassidy, J. (1988). Child-mother attachment and the self in six-year-olds. Child Development, 59 (1), 121-134.

Cassidy, J., Shaver, R. (2008). Eds. Handbook of Attachment: Theory, Research, and Clinical Applications, Second Edition. The Guilford Press: New York, NY $1020 \mathrm{pp}$

Czub, M. (2003). Znaczenie wczesnych więzi społecznych dla rozwoju emocjonalnego dziecka. Forum Oświatowe, 2 (29), 31-49.

Declercq, F., Willemsen, J. (2006). Distress and Post-Traumatic Stress Disorders in High Risk Professionals: Adult Attachment Style and the Dimensions of Anxiety and Avoidance. Clinical Psychology and Psychotherapy, 13, 256-263.

Endler, N. S., \& Parker, J. D. A. (1990). Multidimensional Assessment of Coping: A Critical Evaluation. Journal of Personality and Social Psychology, 58 (5), 844-854.

Folkman S, Moskowitz J.T, 2004 Coping: Pitfalls and promise. Annual Review of Psychology 55, 745-774.

Franczak, K. (2012). Attachment Styles and the Ways of Coping with Stress in Polish Nurses. Advances in Palliative Medicine, 11 (2), 62-73. 
Gentzler, A.L., Kerns, K.A. (2004). Associations between insecure attachment and sexual experiences. Personal Relationships, 2 (11), 249-265.

Greenberg, M. T. (1999). Attachment and psychopathology in childhood. In J. Cassidy and P. R. Shaver (Eds.), Handbook of attachment: Theory, research, and clinical applications (pp. 469-496). New York: Guilford Press.

Hanak, N. (2004). Konstruisanje novog instrumenta za procenu afektivnog vezivanja kod odraslih i adolescenata - UPIPAV. [Designing a new instrument for assessing affective attachment in adults and adolescents - UPIPAV] Psihologija, 37 (1), $123-141$.

Hanak, N. (2011). Snage, slabosti i mogući pravci daljeg razvoja skale UPIPAV-R. [Strengths, weaknesses and possible directions for further development of the scale UPIPAV-R] Saopštenje na skupu Savremeni trendovi u psihologiji. Novi Sad. Knjiga rezimea: $275-276$.

Hanak, N., Dimitrijević, A. (2013) A Serbian Version of Modified and Revised Experiences in Close Relationships Scale (SM-ECR-R). Journal of Personality Assessment, 95 (5), 530-8. doi: 10.1080/00223891.2013.778271.

Hobdy, J., Hayslip, B., Kaminski, P. L., Crowley, B. J., Riggs, S., \& York, C. (2007). The role of attachment style in coping with job loss and the empty nest in adulthood. The International Journal of Aging and Human Development, 65 (4), 335-371.

Holmberg, D., Lomore, C. D., Takacs, T. A., \& Price, E. L. (2011). Adult attachment styles and stressor severity as moderators of the coping sequence. Personal Relationships, 18 (3), 502-517.

Holmes, J. (1993). John Bowlby and Attachment Theory. London: Routledge.

Kostić, A., Nedeljković, J. (2013). Studije vremenskih perspektiva u Srbiji. [Study of Time Perspective in Serbia] Niš: Punta ISBN 978-86-7990-106-4

Kuczyńska, A. (2001). The attachment style and behavior of binding. Czasopismo Psychologiczne, 7, 7-15.

Komorowska-Pudło M., (2016). The attachment style and stress coping strategies in adult men and women, Polskie Forum Psychologiczne, tom 21, numer 4, s. 573-588

Lazarus, R.S., Folkman, S. (1984). Stress, Appraisal, and Coping. Springer Publishing

Lieberman M., Doyle A.B., Markiewicz D. (1999) Developmental patterns in security of attachment to mother and father in late childhood and early adolescence: associations peer relations, Child Development. 70 (1), 202-13.

Marchwicki, P. (2012). Patologia rodzinna a zaburzenia psychiczne i zaburzenia zachowania u dzieci i młodzieży w kontekście teorii przywiązania [Dysfunctional families and mental and behavioural disorders in children and adolescents in the context of the attachment theory]. Homines Hominibus, 8, 161-172.Main, M. and Solomon, J. (1986). Discovery of an Insecure Disoriented Attachment Pattern: Procedures, Findings and Implications for the Classification of Behavior. In: Brazelton, T.B. and Yogman, M.W., Eds., Affective Development in Infancy, Ablex, Norwood, 95-124.

Mikulincer, M. (1995). Attachment style and the mental representation of the self. Journal of Personality and Social Psychology, 6 (69), 1203-1215.

Mikulincer, M., Florian, V., Weller, A. (1993). Attachment style, coping strategies, and posttraumatic psychological distress: The impact of the Gulf War in Israel. Journal of Personality and Social Psychology, 64, 817-826.

Mikulincer, M., Florian, V. (1995). Appraisal of and coping with a real-life stressful situation: The contribution of attachment styles. Personality and Social Psychology Bulletin, 21, 406-414.

Mikulincer, M., Shaver, P.R. (2003). The attachment behavioral system in adulthood: activation, psychodynamics, and interpersonal processes. Advances in Experimental Social Psychology, 35, 53-152. 
Pielage, S., Gerlsma, C., Schaap, C. (2000). Insecure attachment as a risk factor for psychopathology: The role of stressful events. Clinical Psychology and Psychotherapy, 7, 296-302

Plopa, M. (2003). Rozwój i znaczenie bliskich więzi w życiu człowieka [The development and importance of close relationship in human life]. W: B. Wojciszke, M. Plopa (red.), Osobowość a procesy psychiczne i zachowanie [Personality and mental processes and behaviour] (s. 49-79). Kraków: Oficyna Wydawnicza Impuls.

Plopa, M. (2008). Kwestionariusz Stylów Przywiazaniowych (KSP) [The Questionaire of Attachment Styles (QAS )]. Podrecznik. Warszawa: VIZJA PRESS\&IT.

Rostowski, J. (2003). Style przywiązania a kształtowanie się związków interpersonalnych w rodzinie [Attachment styles and development of interpersonal relationships in the family]. W: I. Janicka, T. Rostowska (red.), Psychologia $w$ stużbie rodziny [Psychology in the service of the family] (s. 19-31). Łódź: Wydawnictwo Uniwersytetu Łódzkiego.

Schore, N.A. (2001), Dysregulation of the right brain: a fundamental mechanism of traumatic attachment and the psychopathogenesis of posttraumatic stress disorder, Australian and New Zealand Journal of Psychiatry, 36 (1), 9-30.

Selye, H. (1956). The Stress of Life. McGraw-Hill Book Company

Sroufe, L. A. (1985) Attachment classification from the perspective of infant-caregiver relationships and infant temperament. Child Development. February, 56 (1), 1-14.

Stawicka, M. (2001). Teoria więzi w wyjaśnianiu autodestruktywności [The theory of attachment in explaining autodestuction]. Forum Oświatowe, 2 (25), 93-109.

Stawicka, M. (2008). Autodestruktywność dziecięca w świetle teorii przywiązania [Children/s self-destruction in the attachment theory]. Poznań: Wydawnictwo Naukowe UAM.

Stefanović Stanojević, T. (2010). Afektivna vezanost: razvoj, modaliteti i procena. [Affective attachment: development, modality and assessment] Filozofski fakultet, Niš

Stefanović Stanojević, T., Tošić Radev, M., Stojilković, A. (2017) Strah je najgore mesto: Studija o ranoj traumi iz ugla teorije afektivne vezanosti. [Fear is the worst place: A study of early traumas from the angle of the theory of affective attachment] Centar za primenjenu psihologiju (in press)

Terzi, S. (2013). Secure Attachment Style, Coping with Stress and Resilience Among University Students. The Journal of Happiness \& Well-Being, 1 (2), 101-114.

Troy, M., \& Sroufe, L. A. (1987). Victimization among preschoolers: Role of attachment relationship history. Journal of the American Academy of Child \& Adolescent Psychiatry, 26(2), 166-172.

Zotović, M. (2004). Prevladavanje stresa: konceptualna i teorijska pitanja sa stanovišta transakcionističke teorije. [Overcoming stress: conceptual and theoretical issues from the point of view of transactional theory] Psihologija, 37 (1), 5-32 UDC 159.944.4:159.964.32 


\title{
СТРАТЕГИЈЕ ПРЕВЛАДАВАЫА СТРЕСА И ДИМЕНЗИЈЕ АФЕКТИВНЕ ВЕЗАНОСТИ КОД СТУДЕНАТА
}

\author{
Татјана Стефановић Станојевић $^{1}$, Јасмина Недељковић $^{2}$ \\ ${ }^{1}$ Универзитет у Нишу, Филозофски факултет, Ниш, Србија \\ ${ }^{2}$ Факултет за правне и пословне студије др Лазар Вркатић, Нови Сад, Србија
}

\begin{abstract}
Резиме
Предмет истраживања је питање могуће повезаности различитих одговора на стрес са димензијама афективне везаности. Стратегије превладавања стреса делимо на: 1) Суочавање усмерено на проблем - односи се на решавање проблема или предузимање акције. Усмеравањем на проблем и решавањем проблема мења се однос особа-околина, било путем директне акције или когнитивним реконструисањем. 2) Суочавање усмерено на емоције - овај стил суочавања са стресом има функцију смањивања или лакшег подношења емоционалне напетости изазване стресном ситуацијом. Те стратегије директно не мењају стресну ситуацију. 3) Суочавање избегавањем - односи се на когнитивне, емоционалне или понашајне покушаје удаљавања било од извора стреса или од психичких и телесних реакција на стресор. Непредузимање или избегавање акција усмерених на проблем, негирање спознаје да се догађај десио, осамљивање, потискивање емоција, конзумирање алкохола и дрога, маштање, сањарење, вечерњи изласци и самодеструктивно понашање - неке су од избегавајућих стратегија. Ова категорија суочавања укључује и дистракцију и социјалну диверзију. Дистракција се односи на усмеравање ка новом задатаку који није повезан са стресном ситуацијом. Овај стил је маладаптиван. Социјална диверзија огледа се у појачаном дружењу са људима. Приликом суочавања са претњом, особа се окреће другима да не би мислила на проблем. И ова стратегија спада у маладаптивне. Од чега зависи наш избор? Да ли нас и поводом начина превладавања стреса одређује квалитет раних интеракција са мајком, односно старатељем. Квалитет афективне везаности процењиван је кроз седам димензија. Наиме, у покушају интеграције социјално персонолошког и клиничког приступа феномену везаности, дефинисан је и концепт разумевања квалитета везаности кроз димензије афективне везаности (Ханак, 2004): Неразрешена траума, Лоша регулација беса, Капацитет за ментализацију, Капацитет за коришћење спољашње базе сигурности, Страх од губитка спољашње базе сигурности, Негативна слика о себи, Негативна слика о другима. Већи број димензија омогућава нијансираније разумевање начина функционисања и психичког устројства личности. Због тога смо се у овом истраживању одлучиле за димензионални приступ. Са циљем испитивања наведеног односа, примењени су Упитник суочавања са стресним ситуацијама (ЦИСС, Ендлер и Паркер, 1990) и Упитник за процену димензија афективне везаности (УПИПАВ, Ханак, 2004), а узорак је чинило 152 студента Филозофског факултета. Резултати указују на постојање значајних корелација између начина суочавања са стресом и димензија афективне везаности. Конкретно, превладавање усмерено на проблем у негативној је корелацији са неразрешеном породичном трауматизацијом, страхом од коришћења спољашње базе сигурности и негативним моделом селфа, док је у позитивној корелацији са капацитетом за ментализацију. Превладавање усмерено на емоције и стратегија дистракције позитивно корелирају са страхом од коришћења спољашње базе сигурности, негативним моделом селфа и других и слабом регулацијом беса, при чему је превладавање усмерено на емоције позитивно повезано и са неразрешеном породичном трауматизацијом. На крају, социјална диверзија значајно негативно корелира са неразрешеном траумом и негативим модела селфа и позитивно са страхом и
\end{abstract}


коришћењем спољашње базе сигурности. Резултати регресионе анализе показују да наведене димензије афективне везаности као предиктори објашњавају $21,1 \%$ варијансе стратегије суочавања усмерене на проблем, $13,3 \%$ варијансе стратегије дистракције, 24,6\% варијансе стратегије социјалне диверзије и чак 49,9\% варијансе стратегије превладавања усмерене на емоције. За закључак дискусије добијених резултата издвојићемо само најважније:

- стратегије превладавања стреса повезане су са рано формираним обрасцима афективне везаности;

- особе са дезорганизованим и преокупираним обрасцем афективне везаности склоније су маладаптивним стратегијама суочавања са стресом;

- особе са сигурним и избегавајућим обрасцем афективне везаности склоније су адаптивнијим стратегијама суочавања са стресом. 